Utah State University

DigitalCommons@USU

Articles

Publications

$5-6-2011$

\title{
Woodland Expansion's Influence on Belowground Carbon and Nitrogen in the Great Basin U.S.
}

\author{
Benjamin M. Rau \\ USDA Forest Service \\ Dale W. Johnson \\ University of Nevada, Reno \\ Robert R. Blank \\ USDA, Agricultural Research Service \\ Robin J. Tausch \\ USDA Forest Service \\ Bruce A. Roundy \\ Brigham Young University \\ Richard F. Miller \\ Oregon State University

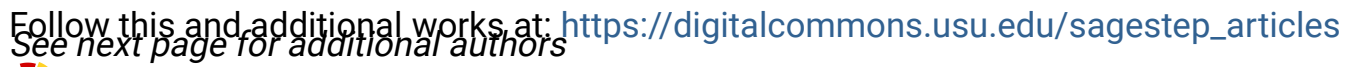 \\ Part of the Plant Sciences Commons
}

\section{Recommended Citation}

Rau, B.M., D.W. Johnson, R.R. Blank, R.J. Tausch, B.A. Roundy, R.F. Miller, T.G. Caldwell and A. Lucchesi. 2011. Woodland expansion's influence on belowground carbon and nitrogen in the Great Basin U.S. Journal of Arid Environments 75:827-835.

This Article is brought to you for free and open access by the Publications at DigitalCommons@USU. It has been accepted for inclusion in Articles by an authorized administrator of DigitalCommons@USU. For more information, please contact digitalcommons@usu.edu.

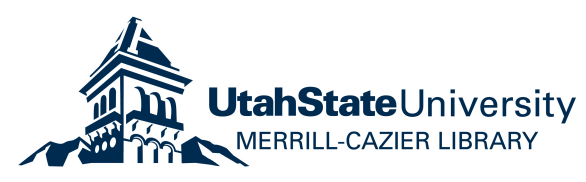




\section{Authors}

Benjamin M. Rau, Dale W. Johnson, Robert R. Blank, Robin J. Tausch, Bruce A. Roundy, Richard F. Miller, Todd G. Caldwell, and Annmarie Lucchesi 


\title{
Woodland expansion's influence on belowground carbon and nitrogen in the Great Basin U.S.
}

\author{
Benjamin M. Rau ${ }^{\mathrm{a}, *}$, Dale W. Johnson ${ }^{\mathrm{b}}$, Robert R. Blank ${ }^{\mathrm{c}}$, Robin J. Tausch ${ }^{\mathrm{d}, 1}$, Bruce A. Roundy ${ }^{\mathrm{e}, 2}$, \\ Richard F. Miller ${ }^{\mathrm{f}, 3}$, Todd G. Caldwell ${ }^{\mathrm{g}, 4}$, Annmarie Lucchesi ${ }^{\mathrm{h}, 5}$ \\ ${ }^{a}$ USDA Forest Service, Wallowa Whitman National Forest, 3502 Highway 30, La Grande, Oregon 97850, USA \\ ${ }^{\mathrm{b}}$ University of Nevada, Reno, Dept. Natural Resources and Environmental Science, Reno, NV 89512, USA \\ ${ }^{c}$ USDA Agicultural Research Service, Reno, NV 89512, USA \\ ${ }^{\mathrm{d}}$ USDA Forest Service RMRS, Reno, NV 89512, USA \\ ${ }^{\mathrm{e}}$ Brigham Young University, Department of Integrative Biology, Provo, UT 84602-5181, USA \\ ${ }^{\mathrm{f}}$ Oregon State University, Department of Rangeland Ecology and Management, Corvallis, OR 97331-2218, USA \\ ${ }^{\mathrm{g}}$ Desert Research Institute, Division of Earth and Ecosystem Sciences, Reno, NV 89512-1095, USA \\ ${ }^{\mathrm{h}}$ USDA Forest Service RMRS, Reno, NV 89512, USA
}

\section{A R T I C L E I N F O}

\section{Article history:}

Received 7 August 2010

Received in revised form

25 November 2010

Accepted 1 April 2011

Available online 6 May 2011

\section{Keywords:}

Pinyon

Juniper

Sagebrush

Carbon

Soil

Tree cover

\begin{abstract}
A B S T R A C T
Vegetation changes associated with climate shifts and anthropogenic disturbance can have major impacts on biogeochemical cycling and soils. Much of the Great Basin, U.S. is currently dominated by sagebrush (Artemisia tridentate (Rydb.) Boivin) ecosystems. Sagebrush ecosystems are increasingly influenced by pinyon (Pinus monophylla Torr. \& Frém and Pinus edulis Engelm.) and juniper (Juniperus osteosperma Torr. and Juniperus occidentalis Hook.) expansion. Some scientists and policy makers believe that increasing woodland cover in the intermountain western U.S. offers the possibility of increased organic carbon $(O C)$ storage on the landscape; however, little is currently known about the distribution of OC on these landscapes, or the role that nitrogen $(\mathrm{N})$ plays in OC retention. We quantified the relationship between tree cover, belowground $\mathrm{OC}$, and total below ground $\mathrm{N}$ in expansion woodlands at 13 sites in Utah, Oregon, Idaho, California, and Nevada, USA. One hundred and twenty nine soil cores were taken using a mechanically driven diamond tipped core drill to a depth of $90 \mathrm{~cm}$. Soil, coarse fragments, and coarse roots were analyzed for $\mathrm{OC}$ and total N. Woodland expansion influenced the vertical distribution of root $\mathrm{OC}$ by increasing $15-30 \mathrm{~cm}$ root $\mathrm{OC}$ by $2.6 \mathrm{Mg} \mathrm{ha}^{-1}$ and root $\mathrm{N}$ by $0.04 \mathrm{Mg} \mathrm{ha}^{-1}$. Root OC and $\mathrm{N}$ increased through the entire profile by 3.8 and $0.06 \mathrm{Mg} \mathrm{ha}^{-1}$ respectively. Woodland expansion influenced the vertical distribution of soil OC by increasing surface soil $(0-15 \mathrm{~cm})$ OC by $2.2 \mathrm{Mg} \mathrm{ha}^{-1}$. Woodland expansion also caused a $1.3 \mathrm{Mgha}^{-1}$ decrease in coarse fragment associated oC from 75 $-90 \mathrm{~cm}$. Our data suggests that woodland expansion into sagebrush ecosystems has limited potential to store additional belowground $\mathrm{OC}$, and must be weighed against the risk of increased wildfire and exotic grass invasion.
\end{abstract}

Published by Elsevier Ltd.

\footnotetext{
* Corresponding author. Tel.: +1541963 7186 .

E-mail addresses: brau02@fs.fed.us (B.M. Rau),dwj@cabnr.unr.edu (D.W.Johnson), blank@unr.nevada.edu (R.R. Blank), bruce_roundy@byu.edu (B.A. Roundy), richard. miller@oregonstate.edu (R.F. Miller), todd.caldwell@dri.edu (T.G. Caldwell), annmarielucchesi@gmail.com (A. Lucchesi).

1 Tel.: +1 7757845329 .

2 Tel.: +18014228137.

3 Tel.: +1541737 1622 .

4 Tel.: +17756737300.

5 Tel.: +1775 7845329 .
}

\section{Introduction}

Anthropogenic disturbance and its influence on vegetation distributions have had significant influence on biogeochemical cycling and soil properties (Schimel et al., 1991, 1994). Historically and currently the Great Basin U.S. has been dominated by sagebrush (Artemisia tridentate) ecosystems. At intermediate elevations with more mesic climates (mean annual precipitation $>20 \mathrm{~cm}$ ), sagebrush ecosystems are increasingly influenced by pinyon (Pinus monophylla, Pinus edulis) and juniper (Juniperus osteosperma, Juniperus occidentalis.) expansion. Pinyon and juniper woodlands have expanded their pre-European settlement range in the Great Basin 
by more than $60 \%$ since 1860 due to a combination of climate change, fire suppression, and livestock grazing (Miller and Wigand, 1994; Gruell, 1999; Miller and Rose, 1999). Although pinyon-juniper woodlands have expanded and receded several times over the last 5000 years, the current rate of expansion is unprecedented. Less than $10 \%$ of current woodlands are of age classes exceeding 140 years (Miller and Tausch, 2001; Miller et al., 2008).

Some scientists and policy makers hypothesize that woodland expansion could result in large increases in organic carbon (OC) storage within the interior western U.S. (Pacala et al., 2001; Asner et al., 2003; Hibbard et al., 2003; Canadell and Raupach, 2008; McKinley and Blair, 2008). Several recent studies have attempted to quantify the influence of pinyon-juniper woodland expansion on aboveground biomass and OC using plot level data and remote sensing techniques (Strand et al., 2008; Huang et al., 2009). While it is true that increasing tree cover could temporarily increase aboveground biomass and $\mathrm{OC}$ storage, much of the $\mathrm{OC}$ in these semi-arid systems is contained belowground, primarily as soil OC (Birdsey, 1992; Rau et al., 2010). The aboveground biomass in arid and semi-arid woodlands cannot be considered stable OC storage due to the frequency of wildfire in these systems (15-90 years), and the threat of exotic grass invasion following wildfire (D'Antonio and Vitousek, 1992; Canadell and Raupach, 2008). Therefore, it is imperative to look more closely at how woodland expansion influences belowground OC pools. There have been initial efforts to quantify belowground $\mathrm{OC}$ changes in expansion woodlands within the intermountain west, but these efforts have typically focused on microsite (tree canopy vs. inter-canopy) level changes or on single sites (Neff et al., 2009; Rau et al., 2009a; Reiley et al., 2010). This study is an attempt to quantify total belowground $\mathrm{OC}$ changes associated with woodland expansion over a broad geographic area, primarily the Great Basin U.S. Also because nitrogen $(\mathrm{N})$ is often limiting in semi-arid systems after water, and because OC and $\mathrm{N}$ cycling are so closely linked, it is important to understand $\mathrm{N}$ pools within these systems as well (Johnson and Curtis, 2001).

Belowground $\mathrm{OC}$ and $\mathrm{N}$ pools are influenced by several factors including: depth to bedrock, coarse fragment content of the regolith, particle size distribution, soil bulk density, type of vegetation, root density and chemistry, and climate (Jobbagy and Jackson, 2000). Over periods of time reasonable to human management concerns (50-200 years), the largest change to belowground OC and $\mathrm{N}$ pools would be a result of changes in vegetation and the resultant change in root distribution, litterfall, and chemistry of the detritus (Jobbagy and Jackson, 2000, 2001).

We studied 13 woodlands sites spread across the interior west. With the data we collected we attempt to address several questions: (1) does woodland expansion affect belowground storage of OC and total N? (2) Does woodland expansion affect the partitioning of root and soil pools of OC and total N? and (3) What are the primary factors associated with belowground $\mathrm{OC}$ and total $\mathrm{N}$ retention in transition woodlands?

\section{Methods}

\subsection{Study area}

This study is part of a Joint Fire Sciences funded project. The Sagebrush Steppe Treatment Evaluation Project (SageSTEP) was designed to determine the effects of woodland expansion and management level fuel reduction treatments on Sagebrush steppe ecosystems (Mclver et al., 2010; www.sagestep.org). Taken together, the 13 woodland sites in the study span a geographic range of more than $800 \mathrm{~km}$ moving from northeast to southwest across Oregon, California, Idaho, Nevada, and Utah U.S.A. The sites represent conditions that vary considerably in elevation, topography, soils, and climate (McIver et al., 2010) (Fig. 1). The 9 sites in Oregon, California, Idaho, and Nevada contained 3 core plots (50-200 ha) which had a fuels reduction treatment implemented after sampling. Treatments include cutting and scattering of trees, prescribed fire, and control plots to monitor change over time. The 4 sites in Utah contained 4 core plots with an additional mastication treatment. All sites are representative of expansion woodlands in which less than $10 \%$ of the trees established before 1850 , and the most rapid rate of expansion occurred between 1920 and 1950 (Miller et al. 2008; Mclver et al. 2010). Within each core plot we sampled three $30 \times 33 \mathrm{~m}$ sub-plots (0.10 ha) which represent a different phase of woodland expansion into sagebrush systems for a total of 129 soil cores (Fig. 1). Phase I plots are shrub and perennial herbaceous species dominated stands. In phase II plots shrubs, perennial herbaceous species, and trees share dominance. Phase III plots are tree dominated stands with limited understory. Basalt lava flows are the dominant parent material in most of northwestern portion of the network, and carbonate parent material dominates the southeastern portion of the study network. Soils within the network are typic aridisols, mollisols, or entisols, most are sandy loam or silt loam texture, and vary in depth from 15 to $>100 \mathrm{~cm}$ (Table 1 ).

\subsection{Sample collection and processing}

Sub-plots were established to quantify vegetation cover and biomass at each location (McIver et al., 2010). In order to minimize disturbance to individual sub-plots we sampled soils on the northeast corner of each plot. At each sub-plot a soil core was taken from inter-canopy areas using a power auger retro-fitted with a diamond tipped core bit (Rau et al., 2009b). This device allows workers to core through large rock fragments and coarse roots to bedrock or a similar obstruction. The device also allows workers to estimate the bulk density of each soil increment if accurate depth measurements are taken. This methodology should provide similar estimates of belowground nutrient pools previously thought obtainable only from quantitative soil pits (Hamburg, 1984; Harrison et al., 2003; Johnson et al., 2007). Soil cores were $7.62 \mathrm{~cm}$ in diameter and taken in $15 \mathrm{~cm}$ increments to a depth of $90 \mathrm{~cm}$ or until an impenetrable obstruction was encountered. Soil cores were placed in plastic lined paper bags, returned to the lab and dried at $50^{\circ} \mathrm{C}$ for $48 \mathrm{~h}$ or until their mass no longer changed. Cores were sieved to $2 \mathrm{~mm}$, and the coarse fragment was submerged and agitated in de-ionized water to separate roots from rocks by flotation, break up soil aggregates which did not pass though the sieve, and to remove adhered soil particles from roots and rocks. Roots and water were decanted off of rocks, and passed through a $0.35 \mathrm{~mm}$ sieve into a drying tray to separate roots from water. Some $<2 \mathrm{~mm}$ sediment remained in with rock samples. The separate rock, root, and water fractions were re-dried at $50^{\circ} \mathrm{C}$. After drying $<2 \mathrm{~mm}$ soil which had been adhered to rocks and roots prior to flotation was again separated from rocks using a $2 \mathrm{~mm}$ sieve. The sediment which was decanted along with roots, but which passed through the $0.35 \mathrm{~mm}$ sieve was removed from the drying tray and added back to the original $<2 \mathrm{~mm}$ fraction along with the second fraction separated from rocks. The mass of all three fractions ( $>2 \mathrm{~mm}$ roots, $>2 \mathrm{~mm}$ coarse fragments, and $<2 \mathrm{~mm}$ soil) was then determined (Fig. 2). Although time consuming we believe this method maximizes separation of fractions and minimizes the cross contamination between fractions. Each fraction was then ground using an Udi cyclone $^{\mathrm{TM}}$ or IKA impact head ${ }^{\mathrm{TM}}$ type mill. Soil and coarse fraction samples were subjected to a test for inorganic carbon using $0.1 \mathrm{M}$ $\mathrm{HCl}$. Samples which tested positive for inorganic C were completely digested with $0.1 \mathrm{M} \mathrm{HCl}$ to remove inorganic C (Sollins et al., 1999). Five samples $(<2 \mathrm{~mm}$ untreated soil, $<2 \mathrm{~mm} \mathrm{HCl}$ treated soil, $>2 \mathrm{~mm}$ untreated coarse fragments, $>2 \mathrm{~mm} \mathrm{HCl}$ treated coarse 

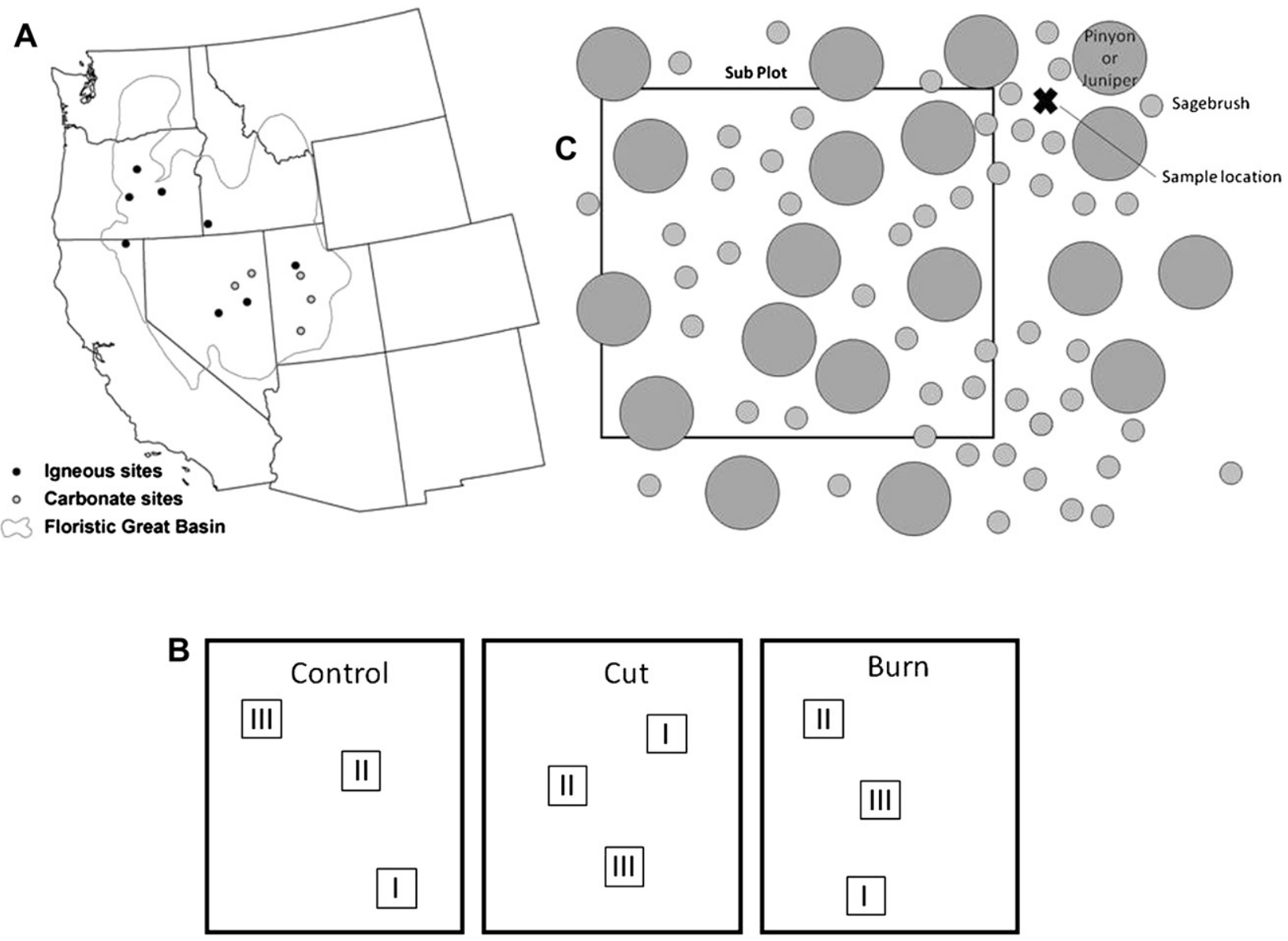

Fig. 1. Location of the 13 woodland sites in the Great Basin, U.S. (Panel A). Generalized sub-plot layout within core plots at each site (Panel B). Sample location at each sub-plot (Panel C).

fragments, and $>2 \mathrm{~mm}$ roots) for each core sample were analyzed using a LECO Truspec ${ }^{\circledR} \mathrm{CN}$ analyzer. For soil and coarse fragment material, the instrument was calibrated using a certified standard containing $1.30 \% \mathrm{C}$ and $0.130 \% \mathrm{~N}$; for roots, the instrument was calibrated using EDTA (41.02\% C, 9.57\% N). The $\mathrm{HCl}$ digest method may remove a small amount of $\mathrm{OC}$ and total $\mathrm{N}$ from the samples which may result in an underestimate of OC \% and total $\mathrm{N} \%$ in our samples (Sollins et al., 1999). Percent OC and total N were multiplied

Table 1

Names, USDA soil classification, parent material, location, elevation, and mean annual precipitation for the 13 woodland research sites within the Sage STEP network.

\begin{tabular}{|c|c|c|c|c|c|c|}
\hline Site & Soil classification & Geology & LAT & LONG & $\begin{array}{l}\text { Elevation } \\
(\mathrm{m})\end{array}$ & $\begin{array}{l}\text { MAP } \\
(\mathrm{mm})\end{array}$ \\
\hline Greenville Bench & Loamy-skeletal, carbonatic, mesic Typic Calcixerepts & $\begin{array}{l}\text { Sedimentry and Igneous colluvium } \\
\text { and alluvium }\end{array}$ & 38.19911781 & -112.78630695 & 1809 & 341 \\
\hline Onaqui & $\begin{array}{l}\text { Loamy-skeletal, carbonatic, mesic, shallow Petrocalcic } \\
\text { Palexerolls }\end{array}$ & Limestone/Sandstone & 40.22845024 & -112.46580100 & 1681 & 339 \\
\hline Scipio & $\begin{array}{l}\text { Loamy-skeletal, mixed, superactive, mesic, shallow Calcic } \\
\text { Petrocalcids }\end{array}$ & Limestone/Sandstone/Volcanics & 39.27556121 & -112.07076752 & 1653 & 389 \\
\hline Stansbury & Loamy-skeletal, mixed, active, frigid Pachic Haploxerolls & Quarzite residuum and colluvium & 40.58223261 & -112.66391834 & 1708 & 410 \\
\hline Marking Corral & $\begin{array}{l}\text { Loamy-skeletal, mixed, superactive, mesic Argidic } \\
\text { Durixerolls }\end{array}$ & Andesite and Quartz alluvium & 39.39504180 & -115.15653759 & 2116 & 329 \\
\hline Seven Mile & Loamy-skeletal, mixed, frigid Lithic \& Typic Argixerolls & Volcanic residuum and alluvium & 39.00943042 & -116.41220704 & 2253 & 253 \\
\hline $\begin{array}{l}\text { South Ruby } \\
\text { Mountain }\end{array}$ & $\begin{array}{l}\text { Loamy, mixed, superactive, mesic, shallow Haploduridic } \\
\text { Durixerolls }\end{array}$ & Sedimentry and Igneous alluvium & 40.05398705 & -115.65100408 & 1920 & 356 \\
\hline $\begin{array}{l}\text { Spruce } \\
\text { Mountain }\end{array}$ & $\begin{array}{l}\text { Loamy, mixed, superactive, mesic, shallow Haploduridic } \\
\text { Durixerolls }\end{array}$ & Sedimentry and Igneous alluvium & 40.50571010 & -114.78944879 & 2119 & 356 \\
\hline Blue Mountain & Loamy, mixed, superactive, mesic Lithic Haploxerolls & Basalt residuum & 41.84080428 & -120.87214479 & 1594 & 492 \\
\hline Bridge Creek & $\begin{array}{l}\text { Sandy loam, Frigid Typic Haploxerolls to Frigid } \\
\text { Torriorthents }\end{array}$ & Basalt residuum & 44.59814725 & -120.20118828 & 850 & 303 \\
\hline Castlehead & $\begin{array}{l}\text { Loamy-skeletal, mixed, superactive, frigid Ultic } \\
\text { Argixerolls }\end{array}$ & Basalt residuum & 42.44660147 & -116.75442623 & 1598 & 312 \\
\hline Devine Ridge & $\begin{array}{l}\text { Loamy-skeletal, mixed, superactive, frigid Lithic } \\
\text { Haploxerolls }\end{array}$ & Basalt residuum & 43.70977658 & -118.95744729 & 1490 & 369 \\
\hline Walker Butte & Ashy, glassy, frigid Vitritorrandic Durixerolls & $\begin{array}{l}\text { Volcanic ash and Loess over } \\
\text { Basalt residuum }\end{array}$ & 43.52634039 & -120.66870226 & 1421 & 259 \\
\hline
\end{tabular}




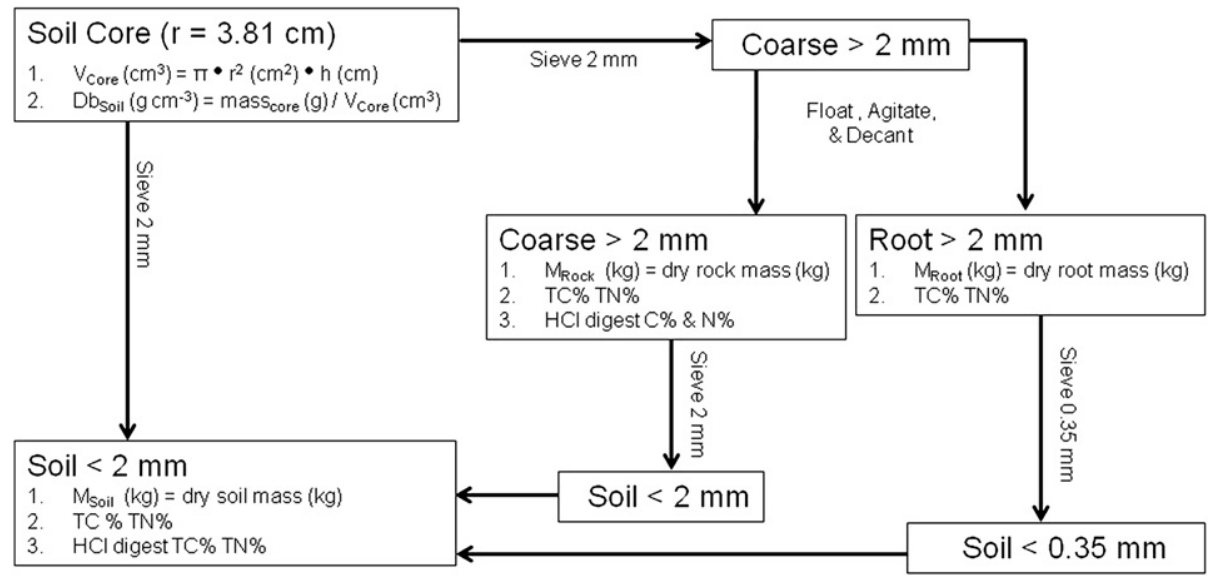

\footnotetext{
Roots $>2 \mathrm{~mm}\left(\mathrm{Kg} \mathrm{ha}^{-1}\right)=\left\{\mathrm{M}_{\text {Root }}(\mathrm{kg}) / \mathrm{V}_{\text {core }}\left(\mathrm{cm}^{3}\right)\right\} \cdot \mathrm{d}(\mathrm{cm}) \cdot 100,000,000\left(\mathrm{~cm}^{2}\right) \cdot \mathrm{C}$

Coarse $>2 \mathrm{~mm}\left(\mathrm{Kg} \mathrm{ha}^{-1}\right)=\left\{\mathrm{M}_{\text {coarse }}(\mathrm{kg}) / \mathrm{V}_{\text {core }}\left(\mathrm{cm}^{3}\right)\right\} \cdot \mathrm{d}(\mathrm{cm}) \cdot 100,000,000\left(\mathrm{~cm}^{2}\right) \cdot \mathrm{C}$

Soil $<2 \mathrm{~mm}\left(\mathrm{Kg} \mathrm{ha}^{-1}\right)=\left\{\mathrm{M}_{\text {Soil }}(\mathrm{kg}) / \mathrm{V}_{\text {core }}\left(\mathrm{cm}^{3}\right)\right\} \cdot \mathrm{d}(\mathrm{cm}) \cdot 100,000,000\left(\mathrm{~cm}^{2}\right) \cdot \mathrm{C}$

Where $(C)=$ nutrient concentration in fraction $\%$ and $(d)=$ depth of the core increment
}

Fig. 2. Sample processing regime, and unit conversion for each core increment extracted.

by each sample fraction's mass to obtain the mass of OC and total $\mathrm{N}$ per core sample. Dividing each fraction's OC and total $\mathrm{N}$ mass by the core volume and multiplying by the sample depth gives the mass of $\mathrm{OC}$ and total $\mathrm{N}$ per sample per unit area, and the sum of all samples from each core gives total OC and total N per unit area (Fig. 2).

\subsection{Statistical analyses}

Five variables for belowground $\mathrm{OC}$ were analyzed for the influence of woodland expansion, soil depth, and their interactions: soil OC percent, soil OC content, root OC content, coarse fraction OC content, and total belowground OC. Similarly, six variables for total belowground $\mathrm{N}$ were analyzed: soil $\mathrm{N}$ percent, soil $\mathrm{N}$ content, root $\mathrm{N}$ content, content coarse fraction $\mathrm{N}$ content, total belowground $\mathrm{N}$, and $\mathrm{C}: \mathrm{N}$.

All comparisons were evaluated using $\mathrm{SAS}^{\mathrm{TM}}$ generalized linear mixed models (Proc GLIMMIX). Differences in OC and total $\mathrm{N}$ were evaluated by treating phase of woodland expansion as main effect, soil depth was a split plot within phase of woodland expansion, and site was a considered a random affect (alpha $=0.05$ ). Means comparisons were made using Tukey's test (alpha $=0.05$ ).

Stepwise linear regression (SAS ${ }^{\mathrm{TM}}$ Proc REG) was used to determine the main factors related to total belowground $O C$ (root $\mathrm{OC}+$ soil $\mathrm{OC}+$ rock $\mathrm{OC}$ ) retention in expansion woodlands. The main factors included in the analyses were coarse fragment \%, sand $\%$, silt \%, clay \%, total belowground N, mean annual precipitation, mean annual temperature, tree cover, shrub cover, and perennial herbaceous cover. The regression analyses use an iterative process to find the best models for each number of variables utilized by the model. The criteria used to identify the best-fit model are a high adjusted $r^{2}$ and low values for the Delta Akaike Information Criterion (AIC), and the Delta Baysian Criterion (BIC).

\section{Results and discussion}

\subsection{Carbon}

Means comparisons suggested woodland expansion may lead to higher amount of root OC in phase III vs. phase I woodlands (Fig. 3).
Root OC was 2.6 $\mathrm{Mg} \mathrm{ha}^{-1}$ higher in the $15-30 \mathrm{~cm}$ depth increment in phase III woodland plots and mimics root distributions of Great Basin plant species (Fig. 4). Perennial grasses, forbs, and shrub species in the Great Basin tend to have roots concentrated in the top $20 \mathrm{~cm}$ of soil (Rau et al., 2009b). Pinyon pine and juniper tend to have roots concentrated below $20 \mathrm{~cm}$ (Rau et al., 2009b). The increase in roots below $20 \mathrm{~cm}$ in phase III woodland plots is indicative of the vegetation transition occurring on the landscape. Increasing tree cover resulted in $3.9 \mathrm{Mg} \mathrm{ha}^{-1}$ of additional root OC through the soil profile to $90 \mathrm{~cm}$ in our woodland plots (Figs. 3 and 4).

Tukey's tests suggest that increasing tree cover affected the distribution of soil OC within the soil profile (Fig. 4). Phase III woodland plots tended to have higher soil OC concentration and content in the first $15 \mathrm{~cm}$ (Fig. 4). The pattern of soil OC redistribution in Phase III woodland plots is consistent with forest soils as described by Jobbagy and Jackson (2000). The mechanism responsible for the increase in soil $O C$ at $0-15 \mathrm{~cm}$ is likely the

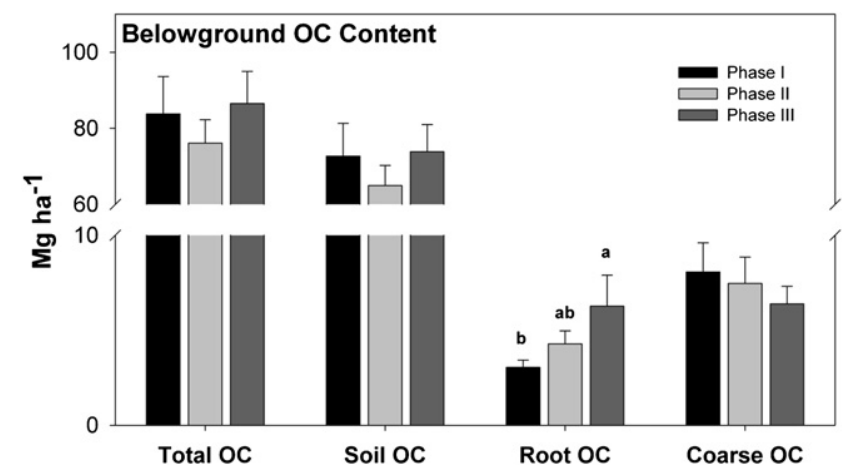

Fig. 3. Means and standard errors by phase of woodland expansion for total belowground organic carbon content, soil organic carbon content, root organic carbon content, coarse fragment organic carbon content, and soil organic carbon percent Lowercase letters represent statistical groups determined by the phase term in the generalized linear mixed model and Tukey's means comparisons $(P<0.05)$. Means not represented by a similar letter are different. 

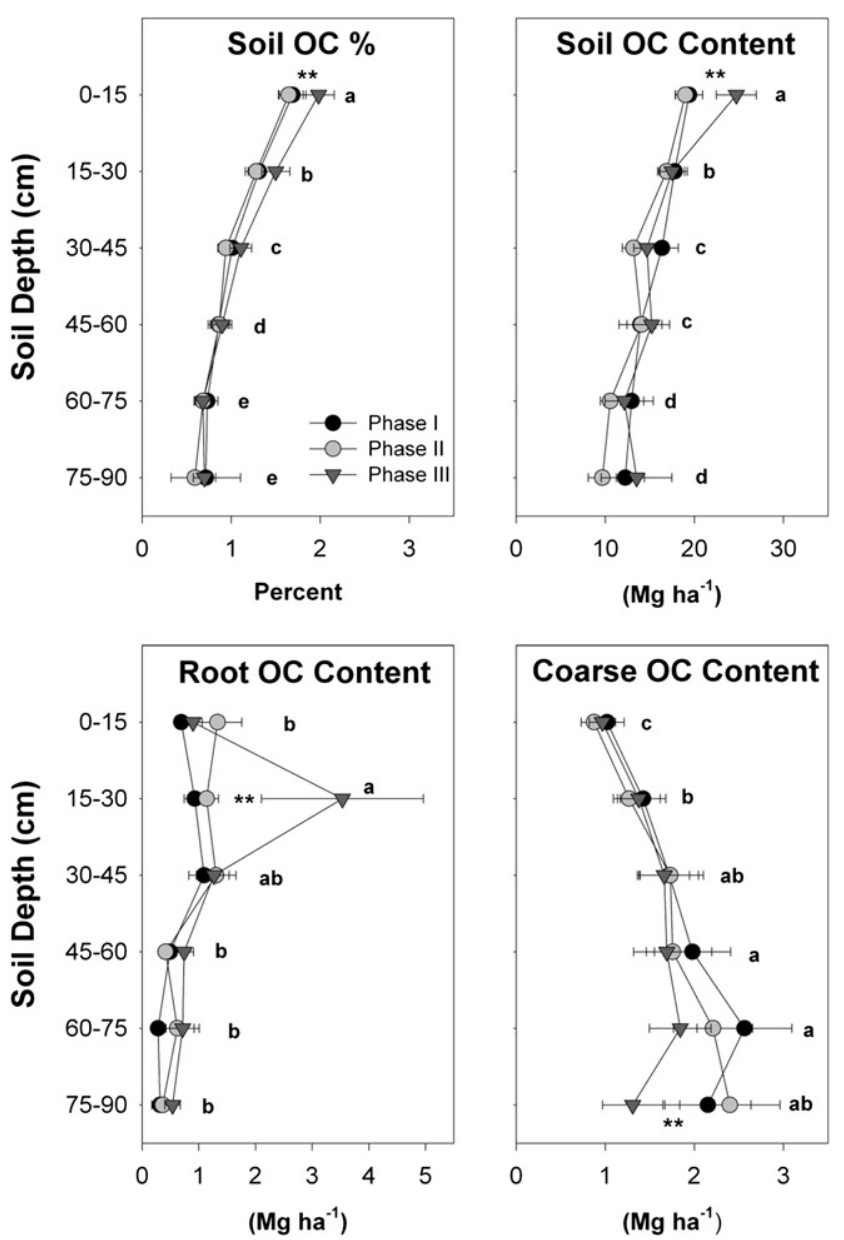

Fig. 4. Means and standard errors by phase of woodland expansion and soil depth increment for percent soil organic carbon, soil organic carbon content, root organic carbon content, and coarse fragment organic carbon content. Lowercase letters represent statistical groups for differences determined by the depth term in the generalized linear mixed model and Tukey's means comparisons $(P<0.05)$. Means not represented by a similar letter are different. Asterisks indicate differences determined by the phase by depth interaction term in the generalized linear mixed model and Tukey's means comparisons $(P<0.05)$.

increased litterfall from trees and the incorporation and redistribution of soil OC into near surface soils. (Richter et al., 1999; Jobbagy and Jackson, 2000). The increased soil OC at $0-15 \mathrm{~cm}$ results in an additional $5 \mathrm{Mg} \mathrm{ha}^{-1}$ of soil OC in high tree density woodland plots (Fig. 4). The lack of response in soil OC to increases in root OC at $15-30 \mathrm{~cm}$ is interesting given that roots and their decomposition are often considered a significant source of soil OC (Schlesinger, 1977). The discontinuity between root OC and soil OC at the $15-30 \mathrm{~cm}$ increment may be a result of the persistence of coarse roots, but complete and rapid fine root turnover (Richter et al., 1999). Because the high-density woodlands in our study have been on the landscape for less than 150 years we may not be able to detect small changes in soil OC caused by root inputs.

Means comparisons also suggest woodland expansion decreased OC associated with coarse fragments in the sub-surface $75-90 \mathrm{~cm}$ increment by $1.0 \mathrm{Mg} \mathrm{ha}^{-1}$ and potentially $2.0 \mathrm{Mg} \mathrm{ha}^{-1}$ though the entire soil profile to $90 \mathrm{~cm}$ (Fig. 4). It is unclear at this time what would cause this decrease in coarse fragment associated OC in expansion woodlands. In our study we determined that OC associated with coarse fragments contributed $10 \%$ of total belowground OC estimates. Researchers have previously documented that coarse fragment OC can account for as much as $20-50 \%$ of total belowground OC.

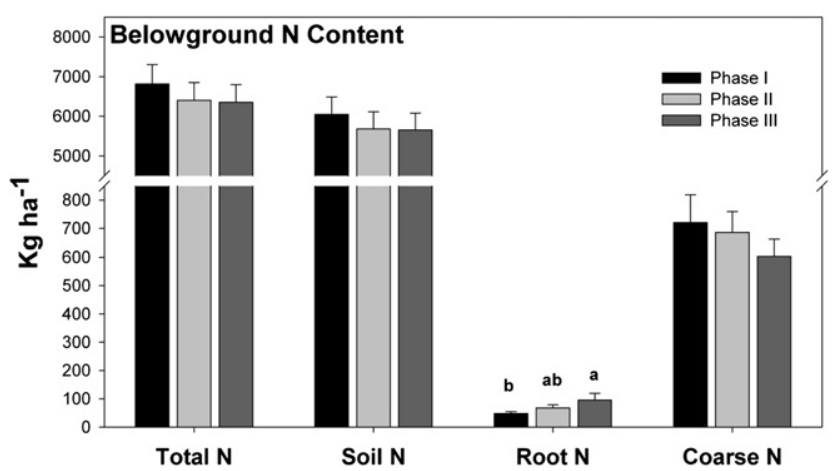

Fig. 5. Means and standard errors by phase of woodland expansion for total belowground nitrogen content, soil nitrogen content, root nitrogen content, and coarse fragment nitrogen content. Lowercase letters represent statistical groups for differences determined by the phase term in the Generalized Linear mixed Model and Tukey's means comparisons $(P<0.05)$. Means not represented by a similar letter are different.

\subsection{Nitrogen}

Woodland expansion increased total root $\mathrm{N}$ by $56 \mathrm{~kg} \mathrm{ha}^{-1}$ in our phase III plots (Fig. 5). The pattern of root $\mathrm{N}$ accumulation is identical to root $\mathrm{OC}$ with over $40 \mathrm{~kg} \mathrm{ha}^{-1}$ of additional root $\mathrm{N}$
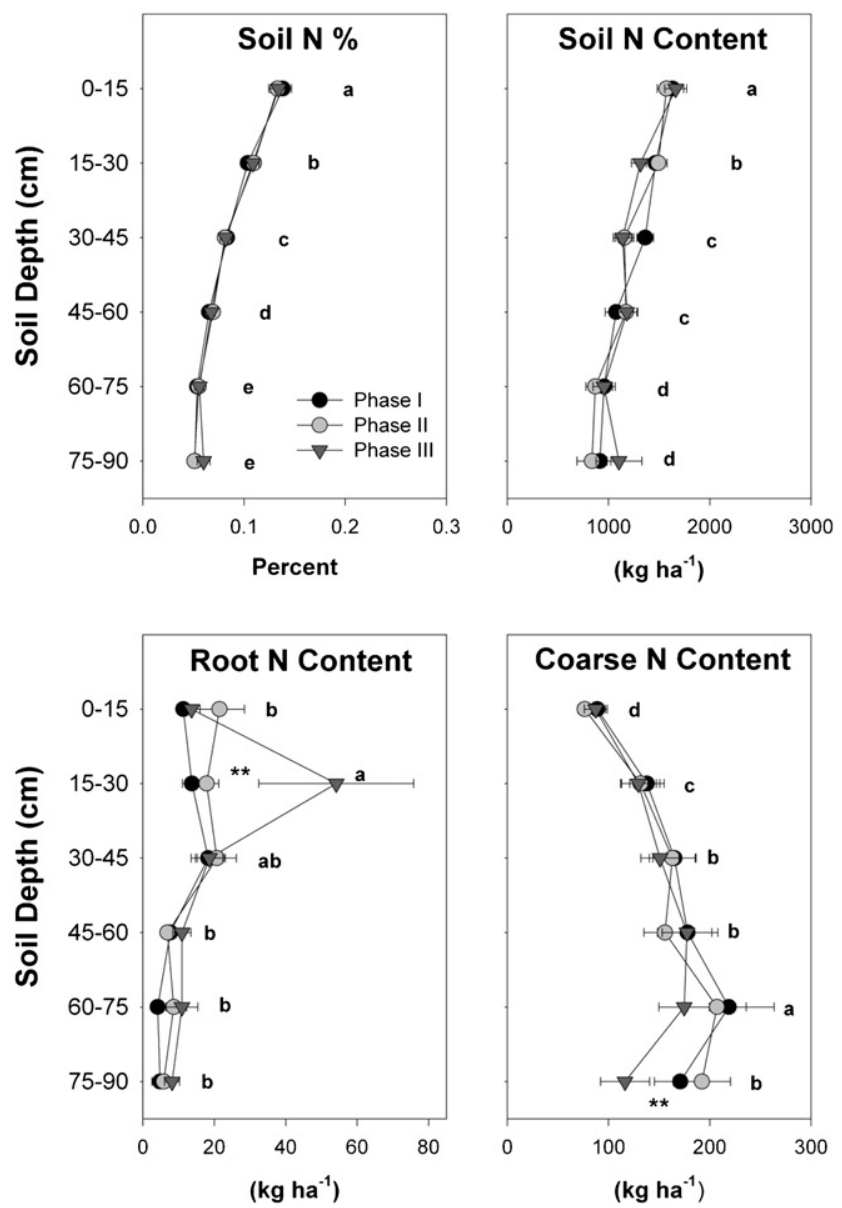

Fig. 6. Means and standard errors by phase of woodland expansion and soil depth increment for percent soil nitrogen, soil nitrogen content, root nitrogen content, and coarse fragment nitrogen content. Lowercase letters represent statistical groups for differences determined by the depth term in the generalized linear mixed model and Tukey's means comparisons $(P<0.05)$. Means not represented by a similar letter are different. Asterisks indicate differences determined by the phase by depth interaction term in the generalized linear mixed model and Tukey's means comparisons $(P<0.05)$. 


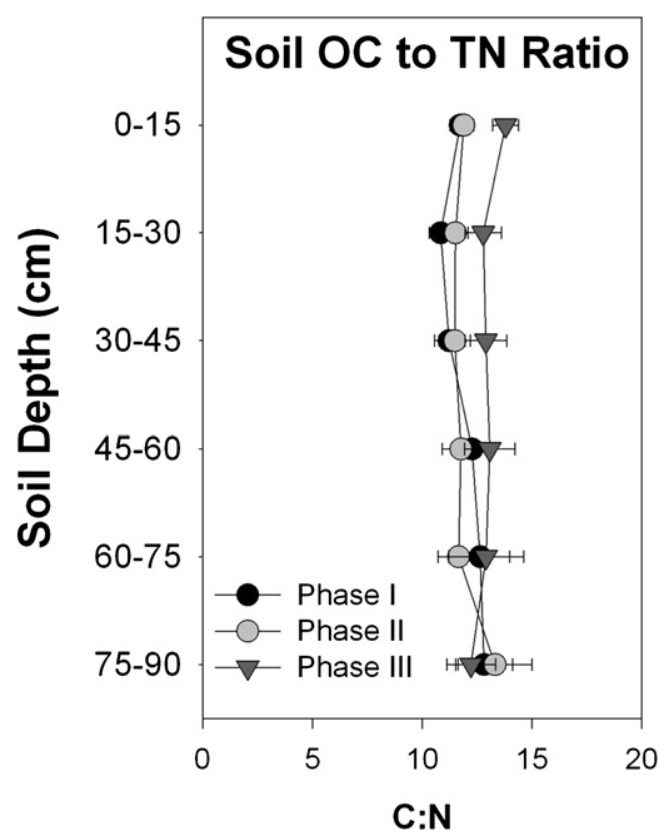

Fig. 7. Means and standard errors by phase of woodland expansion and soil depth increment for the ratio of total soil organic carbon content to total soil nitrogen content.

observed at the $15-30 \mathrm{~cm}$ depth increment in phase III woodland plots (Fig. 6).

Also, similar to the distribution of soil $\mathrm{OC}$, soil $\mathrm{N}$ typically decreases with depth and does not reflect the increased $\mathrm{N}$ found in roots from 15 to $30 \mathrm{~cm}$ (Fig. 6). The discontinuity between root and soil pools for $\mathrm{N}$ could be due to the same mechanisms described for $\mathrm{OC}$, or to the high demand for $\mathrm{N}$ within the soil. Nitrogen may persist in coarse roots and not be available for uptake, but $\mathrm{N}$ from fine roots which turnover rapidly may be re-absorbed by plants and incorporated into aboveground biomass along with additional soil $\mathrm{N}$. There is a weak pattern of decreasing soil $\mathrm{N}$ with increasing tree cover (Fig. 5), and increasing C:N in phase III woodland plots (Fig. 7). Close inspection of our data indicates that soil $\mathrm{N}$ is decreasing in the same depth increments where root $\mathrm{OC}$ and $\mathrm{N}$ are accumulating. This could be a result of mining of soil $\mathrm{N}$ and incorporation of $\mathrm{N}$ into above and belowground biomass. Unlike $\mathrm{OC}$ there was no increase of $\mathrm{N}$ near the soil surface in expansion woodlands (Fig. 6). We believe this further emphasizes that trees are mining the soil for $\mathrm{N}$ and incorporating it into aboveground biomass, then depositing high $\mathrm{C}: \mathrm{N}$ material onto the soil surface. This has been suggested as a mechanism by which woody species invade grass dominated ecosystems (Laungani and Knops, 2009). Analyses of tree, shrub, and herbaceous litter confirmed that tree litter has a higher $\mathrm{C}$ : $\mathrm{N}$ than shub and herbaceous litter.

Nitrogen content of the coarse fraction is not typically measured, but may account for $10 \%$ of total belowground $\mathrm{N}$ estimated to $90 \mathrm{~cm}$ on our plots. It appears that this pool could be up to 10 times larger than the amount of $\mathrm{N}$ found in root biomass (Fig. 5). The $\mathrm{N}$ bound in coarse material could be of several forms: organic and inorganic $\mathrm{N}$ which has been incorporated into pores or cracks within the rock surface, organic and inorganic $\mathrm{N}$ bound into sedimentary deposits, and inorganic $\mathrm{N}$ which has been bound into silicate minerals (Ugolini et al., 1996; Holloway and Dahlgren, 1999; Bohn et al., 2001; Holloway et al., 2001; Corti et al., 2002; Koele and Hildebrand, 2008). We hypothesize that most of the $\mathrm{N}$ associated with coarse fragments is in the form of organic matter which is adhered to the fragment's surface. Even with careful washing of coarse fragments this pool remains quite large. We agree with other researchers that not considering coarse fraction nutrients results in a significant underestimate of belowground pools (Fernandez et al., 1993; Ugolini et al., 1996; Corti et al., 1998; Harrison et al., 2003).

Within the soil profile coarse fraction $\mathrm{N}$ increased with depth to $75 \mathrm{~cm}$ which is consistent with the pattern of OC and coarse fragment distribution through the soil profile (Fig. 6). Given nitrogen's strong relationship to $\mathrm{OC}$ and its likelihood of being a limiting nutrient in soils, pools of OC and $\mathrm{N}$ in coarse fragments should not be overlooked (Koele and Hildebrand, 2008).

\subsection{Factors related to carbon retention}

The stepwise regression analyses suggest that total belowground $\mathrm{OC}$ is consistently and positively correlated with total belowground $\mathrm{N}$. This analysis confirms that total belowground $\mathrm{N}$ is

Table 2

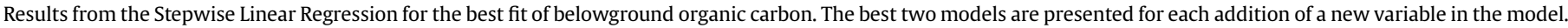

\begin{tabular}{|c|c|c|c|c|c|c|c|c|c|c|c|c|}
\hline $\begin{array}{l}\text { No. of variables } \\
\text { in model }\end{array}$ & Variable 1 & Variable 2 & Variable 3 & Variable 4 & Variable 5 & Variable 6 & Variable 7 & Variable 8 & Variable 9 & Variable 10 & Variable 11 & $r$-Square \\
\hline 1 & Depth & & & & & & & & & & & 0.047 \\
\hline 1 & $\mathrm{TN}$ & & & & & & & & & & & 0.597 \\
\hline 2 & Coarse \% & $\mathrm{TN}$ & & & & & & & & & & 0.626 \\
\hline 2 & $\mathrm{TN}$ & Herb & & & & & & & & & & 0.629 \\
\hline 3 & Coarse $\%$ & $\mathrm{TN}$ & Tree & & & & & & & & & 0.641 \\
\hline 3 & Coarse \% & $\mathrm{TN}$ & Herb & & & & & & & & & 0.654 \\
\hline 4 & Coarse \% & TN & Tree & Herb & & & & & & & & 0.658 \\
\hline 4 & Coarse \% & $\mathrm{TN}$ & Shrub & Herb & & & & & & & & 0.661 \\
\hline 5 & Coarse \% & Clay \% & TN & Shrub & Herb & & & & & & & 0.662 \\
\hline 5 & Depth & Coarse \% & $\mathrm{TN}$ & Shrub & Herb & & & & & & & 0.662 \\
\hline 6 & Coarse \% & Sand \% & Clay $\%$ & $\mathrm{TN}$ & Tree & Herb & & & & & & 0.664 \\
\hline 6 & Coarse \% & Sand \% & Clay \% & TN & Shrub & Herb & & & & & & 0.665 \\
\hline 7 & Coarse \% & Sand \% & Clay \% & TN & MAT & Shrub & Herb & & & & & 0.666 \\
\hline 7 & Coarse \% & Sand \% & Clay \% & TN & Tree & Shrub & Herb & & & & & 0.666 \\
\hline 8 & Coarse \% & Sand \% & Clay \% & $\mathrm{TN}$ & MAT & Tree & Shrub & Herb & & & & 0.667 \\
\hline 8 & Coarse \% & Sand \% & Clay \% & $\mathrm{TN}$ & MAP & MAT & Shrub & Herb & & & & 0.668 \\
\hline 9 & Depth & Coarse \% & Sand \% & Clay \% & $\mathrm{TN}$ & MAP & MAT & Shrub & Herb & & & 0.668 \\
\hline 9 & Coarse \% & Sand \% & Clay \% & $\mathrm{TN}$ & MAP & MAT & Tree & Shrub & Herb & & & 0.668 \\
\hline 10 & Coarse \% & Sand \% & Silt \% & Clay \% & $\mathrm{TN}$ & MAP & MAT & Tree & Shrub & Herb & & 0.668 \\
\hline 10 & Depth & Coarse \% & Sand \% & Clay \% & $\mathrm{TN}$ & MAP & MAT & Tree & Shrub & Herb & & 0.668 \\
\hline 11 & Depth & Coarse $\%$ & Sand \% & Silt \% & Clay $\%$ & $\mathrm{TN}$ & MAP & MAT & Tree & Shrub & Herb & 0.668 \\
\hline
\end{tabular}

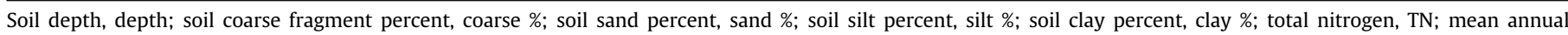
precipitation, MAP; mean annual temperature, MAT; percent shrub cover, Shrub; percent perennial herbaceous cover, Herb; and percent tree cover, tree. 
the single most important factor for belowground $\mathrm{OC}$ retention and explains nearly $60 \%$ of the variance (Table 2). Vegetation fixes atmospheric $\mathrm{CO}_{2}$ and creates plant parts with $\mathrm{C}: \mathrm{N}$ of 30:1 or greater. This biomass is subject to microbial decomposition and can eventually become soil $\mathrm{OC}$ with mean $\mathrm{C}: \mathrm{N}$ close to $12: 1$. The initial chemical composition of the plant material, microbial metabolism, micro-aggregation, and organo-mineral complexion regulates the final C:N of soil OC, but the mean ratio tends not to range far from 12:1 (Lal, 2008; von Lutzow et al., 2008). Therefore, soil OC may not readily accumulate without a concurrent increase in soil $\mathrm{N}$ (Lal, 2008).

The regression also indicates there are consistent positive relationships between total belowground OC and soil depth, coarse fragment \%, sand \%, and clay \%. Inclusion of variables which define soil depth and texture explains an additional $3 \%$ of the variance (Table 2). It is not surprising that deeper soil profiles store more OC than shallow soil profiles, and it has been well documented that soils with high clay content also store more OC due to the ability of clay particles to form decomposition resistant organo-mineral complexes with soil OC (von Lutzow et al., 2008). It was somewhat surprising to find a positive relationship between total belowground $O C$ and coarse fragment and sand percentage. However, it is plausible that coarse grained soil texture facilitates incorporation of tree litter into surface soils, therefore, increasing soil OC content.

There are additional positive relationships which occur between total belowground OC, tree cover, and mean annual precipitation; inclusions of variables which define vegetation cover and precipitation explain another $3 \%$ of the modeled variance (Table 2 ). These variables are more related to site productivity and indicate that more productive sites within the pinyon-juniper zone have greater potential for OC accumulation. This is somewhat contrasting to evidence presented by Jackson et al. (2002). The regression model indicated consistent negative correlations of total belowground $\mathrm{OC}$ with shrub cover and perennial herbaceous cover. Cold dessert ecosystems such as the sagebrush steppe typically have very low ratios of aboveground to belowground biomass, and belowground herbaceous biomass is typically a major contributor to belowground OC pools (Jackson et al., 2000). Temperate grasslands often have some of the highest stocks of belowground $\mathrm{OC}$ found in any ecosystem (Jackson et al., 2000). Therefore, it is somewhat surprising to see that reduction of herbaceous understory and shrub cover is associated with increasing belowground $O C$. Resources in semi-arid woodlands are limited, and an increase in woody vegetation cover results in loss of perennial herbaceous and shrub species (Miller and Tausch, 2001). It appears that any reduction in belowground OC caused by the loss of herbaceous species has been offset by the concurrent increased production of belowground biomass and litter from pinyon pine and juniper species. Careful examination of the Jackson et al. (2002) data indicates that woody encroachment does not reduce belowground OC stock until mean annual precipitation (MAP) exceeds 450-500 mm per year (Jackson et al., 2002). Woody encroachment appears to have a more positive influence on belowground $\mathrm{OC}$ below $500 \mathrm{~mm}$ MAP (Jackson et al., 2002). None of our 13 sites have MAP over $500 \mathrm{~mm}$ (Table 1). It is likely that the arid nature of our sites inhibits decomposition; which is favorable to OC accumulation in expansion woodlands to the point where $\mathrm{N}$ limitation occurs (Murphy et al., 1998). Finally, there was a consistent negative relationship between belowground $\mathrm{OC}$ and mean annual temperature (MAT). Increasing temperature increases microbial activity and facilitates decomposition of organic materials; this relationship is not uncommon and has been documented in other semi-arid woodlands (Schimel et al., 1994).

Pinyon and Juniper woodlands occupy approximately 18 million hectares within the Great Basin U.S. Current estimates suggest that only $20 \%$ of current woodlands have reached Phase III, defined as a tree dominated stage with greater than 50\% canopy cover and limited understory vegetation (Miller et al., 2008). If woodlands continue to mature and infill at their present rate, than nearly $75 \%$ of all woodlands will be entering phase III within 30-50 years (Miller et al., 2008). This shift in tree dominance may have dramatic impacts on ecosystem structure and function, increase the risk of catastrophic fire, and leave the landscape susceptible to exotic invasive species such as Bromus tectorum L. (Miller and Tausch, 2001).

Our data suggests that the transition from low density phase I to high density phase III woodland results in an additional $3.9 \mathrm{Mg} \mathrm{ha}^{-1}$ of root OC and $5.1 \mathrm{Mg} \mathrm{ha}^{-1}$ of soil OC sequestration. However, we must also account for an apparent $2.0 \mathrm{Mg} \mathrm{ha}^{-1}$ decrease in coarse fragment associated OC. When extrapolated out to the 18 million ha range of Great Basin woodlands over the $50 \mathrm{yr}$ period estimated for woodland infill there is potential for $139 \mathrm{~kg} \mathrm{ha}^{-1} \mathrm{yr}^{-1}$, or $0.08 \mathrm{Pg}$ of additional total C storage. To put this in perspective $\mathrm{C}$ emissions from the burning of fossil fuels in the 1990s resulted in a $3 \mathrm{Pg}$ net annual increase in atmospheric $\mathrm{CO}_{2}$ (Schimel et al., 2001). Our estimates are less than half of what was reported by Neff et al. (2009) who reported approximately $300 \mathrm{~kg} \mathrm{ha}^{-1} \mathrm{yr}^{-1}$ for soil OC accumulation in juniper woodlands on the Colorado Plateau U.S. However, they estimated inputs directly under tree canopies, and our data is more representative of intercanopy sites. We emphasize that our mean estimates cover a broad geographic area and that rates of accumulation or total accumulation potential will be dependent on site specific variables described in the our regression model.

Although outside of the scope of this study, we can hypothesize that additional OC accumulation will occur in expansion woodlands due to the increase in aboveground biomass. Initial estimates suggest that woodland expansion could increase aboveground $C$ by $20-50 \mathrm{Mg} \mathrm{ha}^{-1}$ (Rau unpublished data). This may contribute another $0.2-0.5 \mathrm{Pg} \mathrm{C}$ throughout the Great Basin over the next 50 years, or approximately $400-1000 \mathrm{~kg} \mathrm{ha}^{-1} \mathrm{yr}^{-1}$. However, this estimate is based on plot level data and is considerably larger than plot level estimates made by Strand et al. (2008) who estimated aboveground OC accumulation rates of $220 \mathrm{~kg} \mathrm{ha}^{-1} \mathrm{yr}^{-1}$ for juniper woodlands on the Owyhee Plateau U.S. Strand et al. (2008) also point out that plot level estimates are considerably larger than estimates of landscape level change made via remote sensing. Clearly these differences will need to be resolved.

The increases in above and belowground OC associated with woodland expansion must be viewed with some caution based on the frequency of fire in semi-arid woodlands, the potential for exotic annual grass invasion, and the potential for drought induced tree mortality (Miller and Tausch, 2001; Breshears et al., 2005; Westerling et al., 2006; Hurteau and North, 2009). Once canopy cover reaches $50 \%$ expansion woodlands become susceptible to high intensity wildfire and exotic annual grass invasion (Miller and Tausch, 2001). Combustion of trees during fire may release $70 \%$ of OC stored in aboveground biomass to the (Rau et al., 2010). It is likely that the majority of remaining dead biomass including roots will decompose and result in further release of $\mathrm{CO}_{2}$ to the atmosphere (Johnson and Curtis, 2001). Similarly, given that much of the soil OC accumulation in expansion woodlands is in the form of nonmineral OC complexes, it is likely that this fraction will decompose and release $\mathrm{CO}_{2}$ following removal of trees (von Lutzow et al., 2008; Neff et al., 2009). Although it has not been widely documented in the Great Basin, as it has been on the Colorado Plateau, the potential for tree mortality from global-change-type drought may result in similar losses in OC as observed from wildfires (Breshears et al., 2005).

The likelihood of exotic annual grass invasion following fire or drought induced mortality could further exacerbate the loss of OC 
from expansion woodlands (Miller and Tausch, 2001). Woodland expansion results in a loss of perennial understory vegetation (Miller and Tausch, 2001). Following fire, exotic annual grasses like cheatgrass are able to establish and dominate a site with compromised understory (Chambers et al., 2007). The conversion of sagebrush steppe or pinyon-juniper ecosystems to annual grass dominated systems results in a large loss of above and belowground OC (Bradley et al., 2006; Rau et al., 2011). Annual grass systems dramatically alter fire regimes and are prone to repeated fire every 2-5 years (D'Antonio and Vitousek, 1992). This dramatically altered fire regime could cause further losses of OC and $\mathrm{N}$ from the system resulting in large potentially irreversible changes in $\mathrm{C}$ and $\mathrm{N}$ cycles (D'Antonio and Vitousek, 1992).

\section{Conclusions}

Our results indicate that woodland expansion has an influence on the vertical distribution and total pools of belowground soil OC, root $\mathrm{OC}$, and root $\mathrm{N}$, and up to $10 \%$ of total belowground OC and $\mathrm{N}$ may be found in coarse fragments. Organic carbon accumulation associated with woodland expansion in the Great Basin U.S. has limited potential to offset annual $\mathrm{CO}_{2}$ emissions, and estimates of potential belowground and aboveground OC accumulation in arid woodlands must be viewed with skepticism based on the frequency of fire, the uncertainty in future climate, the loss of native perennial vegetation, and the risk of post wildfire exotic annual grass invasion.

\section{Acknowledgements}

This paper is Contribution \# 36 of the Sagebrush Steppe Treatment Evaluation Project (SageSTEP). We would like to thank Tye Morgan for assistance in sample processing, and we would like to thank Travis Miller, Brad Jessop, Jamie Ratchford, and all of the field crews for their assistance in gathering tree cover data on the Sage STEP plots.

\section{References}

Asner, G.P., Archer, S., Hughes, F.R., Ansleys, R.J., Wessman, C.A., 2003. Net changes in regional woody vegetation cover and carbon storage in Texas drylands, 1937-1999. Global Change Biology 9, 316-335.

Chambers, J., Roundy, B.A., Blank, R.R., Meyer, S.E., Whitaker, A., 2007. What makes Great Basin sagebrush ecosystems invasible by Bromus tectorum? Ecological Monographs 77, 117

Birdsey, R.A., 1992. Changes in forest carbon storage from increasing forest area and timber growth. In: Sampson, R.N., Hair, D. (Eds.), Forests and Global Change. Opportunities for Increasing Forest Cover, vol. 1. American Forests, Washington, DC, pp. 23-39.

Bohn, H.L., McNeal, B.L., O’Conner, G.A., 2001. Soil Chemistry. John Wiley and Sons, Inc., $307 \mathrm{pp}$.

Breshears, D.D., Cobb, N.S., Rich, P.M., Price, K.P., Allen, C.D., Balice, R.G., Romme, W.H., Kastens, J.H., Floyd, M.L., Belnap, J., Anderson, J.J., Myers, O.B. Meyer, C.W., 2005. Regional vegetation die-off in response to global-changetype drought. Proceedings of the National Academy of Sciences 102 (42), 15144-15148.

Bradley, B.A., Houghton, R.A., Mustard, J.F., Hamburg, S.P., 2006. Invasive grass reduces aboveground carbon stocks in shrublands of the Western US. Global Change Biology 12, 1815-1822.

Canadell, J.G., Raupach, M.R., 2008. Managing forests for climate change mitigation. Science 320, 1456-1457.

Corti, G., Ugolini, F.C., Agnelli, A., Certini, G., Cuniglio, R., Berna, F., Fernandez, M.J., 2002. The soil skeleton, a forgotten pool of carbon and nitrogen in soil. European Journal of Soil Science 53, 283-298.

Corti, G., Ugolini, F.C., Agnelli, A., 1998. Classing the soil skeleton (greater than two millimeters): proposed approach and procedure compared with including the 20 - to 180-cm depths. Soil Science Society of America Journal 62, 1620-1629.

D'Antonio, C.M., Vitousek, P.M., 1992. Biological invasions by exotic grasses, the grass/fire cycle, and global change. Annual Review of Ecological Systems 23, 63-87.

Fernandez, I.J., Rustad, L.E., Lawrence, G.B., 1993. Estimating total soil mass, nutrient content, and trace metals in soils under a low elevation spruce-fir forest. Canadian Journal of Soil Science 73, 317-328.
Gruell, G.E., 1999. Historical and modern roles of fire in pinyon-juniper. In: Monsen, S.B., Stevens, R. (Eds.), Proceedings: Ecology and Management of Pinyon-Juniper Communities in The Interior West. Proceedings RMRS-P-9. United States Department of Agriculture Forest Service Rocky Mountain Research Station, Ogden, UT, pp. 24-28.

Hamburg, S.P., 1984. Effects of forest growth on soil nitrogen and organic matter pools following release from subsistence agriculture. In: Forest Soils and Treatment Impacts. Proceedings of the North American Forest Soils Conference, Knoxville, pp. 145-148.

Harrison, R.B., Adams, A.B., Licata, C., Flaming, B., Wagoner, G.L., Carpenter, P., Vance, E.D., 2003. Quantifying deep-soil and coarse-soil fractions: avoiding sample bias. Soil Science Society of America Journal 67, 1602-1606.

Hibbard, K.A., Schimel, D.S., Archer, S., Ojima, D.S., Parton, W., 2003. Grassland to woodland transitions: integrating changes in landscape structure and biogeochemistry. Ecological Applications 13, 911-926.

Holloway, J.M., Dahlgren, R.A., 1999. Geologic nitrogen in terrestrial biogeochemical cycling. Geology 27 (6), 567-570.

Holloway, J.M., Dahlgren, R.A., Casey, W.H., 2001. Nitrogen release from rock and soil under simulated field conditions. Chemical Geology 174, 403-414.

Huang, C., Asner, G.P., Martin, R.E., Barger, N.N., Neff, J.C., 2009. Multiscale analysis of tree cover and aboveground carbon stocks in pinyon-juniper woodlands. Ecological Applications 19 (3), 668-681.

Hurteau, M., North, M., 2009. Fuel treatment effects on tree-based forest carbon storage and emissions under modeled wildfire scenarios. Frontiers in Ecology and The Environment 7, 409-414.

Jackson, R.B., Banner, J.L., Jobbágy, E.G., Pockman, W.T., Wall, D.H., 2002. Ecosystem carbon loss with woody plant invasion of grasslands. Nature 418, 623-626.

Jackson, R.B., Schenk, H.J., Jobbagy, E.G., Canadell, J., Colello, G.D., Dickinson, R.E., Field, C.B., Friedlingstein, P., Heimann, M., Hibbard, K., Kicklighter, D.W. Kleidon, A., Neilson, R.P., Parton, W.J., Sala, O.E., Sykes, M.T., 2000. Belowground consequences of vegetation change and their treatment in models. Ecological Applications 10 (2), 470-483.

Jobbagy, E.G., Jackson, R.B., 2000. The vertical distribution of soil organic carbon and its relation to climate and vegetation. Ecological Applications 10 (2), 423-436.

Jobbagy, E.G., Jackson, R.B., 2001. The distribution of soil nutrients with depth: global patterns and the imprints of plants. Biogeochemistry 53, 51-77.

Johnson, D.W., Murphy, J.F., Walker, R.F., Glass, D.W., Miller, W.W., 2007. Wildfire effects on forest carbon and nutrient budgets. Ecological Engineering 31, $183-192$.

Johnson, D.W., Curtis, P.S., 2001. Effects of forest management on soil C and $\mathrm{N}$ storage: meta analysis. Forest Ecology and Management 140, 227-238.

Koele, N., Hildebrand, E.E., 2008. The ecological significance of the coarse soil fraction for Picea abies (L.) Kart. Seedling nutrition. Plant and Soil 312, 163-174.

Lal, R., 2008. Promise and limitations of soils to minimize climate change. Journal of Soil and Water Conseration 63, 113-118.

Laungani, R., Knops, J.M.H., 2009. Species-driven changes in nitrogen cycling can provide a mechanism for plant invasions. Proceedings of the National Academy of Sciences 106, 12,400-12,405.

von Lutzow, M., Kogel-Knabner, I., B.LudwigMatzner, E., Flessa, H., Ekschmitt, K., Guggenberger, G., Marschner, B., Kalbitz, K., 2008. Stabalization mechanisms of organic matter in four temperate soils: development and application of a conceptual model. Journal of Plant Nutrition and Soil Science 171, 111-124.

Mclver, J.D., Brunson, M., Bunting, S.C., 2010. The Sagebrush Steppe Treatment Evaluation Project (SageSTEP): a test of state-and-transition theory. Gen. Tech. Rep. RMRS-GTR-237. U.S. Department of Agriculture, Forest Service, Rocky Mountain Research Station, Fort Collins, CO. 16 p.

McKinley, D.C., Blair, J.M., 2008. Woody plant encroachment by Juniperus virginiana in mesic native grassland promotes rapid carbon and nitrogen accrual. Ecosystems 11, 454-468.

Miller, R.F., Wigand, P.E., 1994. Holocene changes in semi arid pinyon-juniper woodlands: response to climate, fire, and human activities in the U.S. Great Basin. Bioscience 44, 465-474.

Miller, R.F., Rose, J.A., 1999. Fire history and western juniper encroachment in sagebrush steppe. Journal of Range Management 52, 550-559.

Miller, R.F., Tausch, R.J., 2001. The role of fire in juniper and pinyon woodlands: a descriptive analysis. In: Gallet, K.E.M., Wilson, T.P. (Eds.), Proceedings of the Invasive Species Workshop: The Role of Fire in the Control and Spread of Invasive Species Tall Timbers Research Station Miscellaneous Publications No. 11, Tallahassee, FL, pp. 15-30.

Miller, R.F., Tausch, R.J., McArthur, E.D., Johnson, D.D., Sanderson, S.C., 2008. Age structure and expansion of pinon-juniper woodlands: a regional perspective in the intermountain west. Research Paper Report RMRS-RP-69. USDA Forest Service Rocky Mountain Research Station, Fort Collins, CO. 15 p.

Murphy, K.L., Klopatek, J.M., Klopatek, C.C., 1998. The effects of litter quality and climate on decomposition along an elevational gradient. Ecological Applications, 1061-1071.

Neff, J.C., Barger, N.N., Baisden, W.T., Fernandez, D.P., Asner, G.P., 2009. Soil carbon storage responses to expanding pinyon-juniper populations in southern Utah. Ecological Applications 19 (6), 1405-1416.

Pacala, S.W., Hurtt, G.C., Baker, D., others, 2001. Consistent land- and atmosphericbased U.S. carbon sink estimates. Science 292, 2316-2320.

Rau, B.M., Johnson, D.W., Blank, R.R., Chambers, J.C., 2009a. Soil carbon and nitrogen in a Great basin pinyon-juniper woodland Influence of vegetation, burning, and time. Journal of Arid Environments 73, 472-479. 
Rau, B.M., Johnson, D.W., Chambers, J.C., Blank, R.R., Luccesi, A., 2009b. Estimating root biomass and distribution after fire in a Great basin woodland using cores and pits. Western North American Naturalist 64 (4), 459-463.

Rau, B.M., Johnson, D.W., Chambers, J.C., Blank, R.R., Luccesi, A., 2010. Influence of prescribed fire on ecosystem biomass, carbon, and nitrogen in a pinyon juniper woodland. Rangeland Ecology and Management 63, 197-202.

Rau, B.M., Johnson, D.J., Blank, R.R., Luchessi, A., Caldwell, T.G., Schupp, E.W., 2011. Transition from sagebrush steppe to annual grass (Bromus tectorum): Influence on below ground carbon and nitrogen. Rangeland Ecology and Management 64, 139-147.

Reiley, D.K., Breshears, D.D., Zedler, P.H., Ebinger, M.H., Meyer, C.W., 2010. Soil carbon heterogeneity in pinon-juniper woodland patches: effect of woody variation on neighboring intercanopies is not detectable. Journal of Arid Environments $74,239-246$

Richter, D.D., Markewitz, D., Trumbore, S.E., Wells, C.G., 1999. Rapid accumulation and turnover of soil carbon in a re-establishing forest. Nature 400, 56-58.

Schimel, D.S., Kittel, T.G.F., Parton, W.J., 1991. Terrestrial biogeochemical cycles: global interactions with the atmosphere and hydrology. Tellus 43AB, 188-203.

Schimel, D.S., Braswell, B.H., Holland, E.A., McKeown, R., Ojima, D.S., Painter, T.H. Parton, W.J., Townsend, A.R., 1994. Climatic, edaphic, and biotic controls over storage and turnover of carbon in soils. Global Biogeochemical Cycles 8, $279-293$.
Schimel, D.S., House, J.I., Hibbard, K.A., Bousquet, P., Ciais, P., Peylin, P., Braswell, B.H., Apps, M.J., Baker, D., Bondeau, A., Canadell, J., Churkina, G., Cramer, W., Denning, A.S., Field, C.B., Friedlingstien, P., Goodale, C., Heinmann, M., Houghton, R.A., Melillo, J.M., Moore III, B., Murdiyarso, D., Noble, I., Pacala, S.W., Prentice, I.C., Raupach, M.R., Rayner, P.J., Scholes, R.J., Steffen, W.L., Wirth, C., 2001. Recent patterns and mechanisms of carbon exchange by terrestrial ecosystems. Nature 414, 169-172.

Schlesinger, W.H., 1977. Carbon balance in terrestrial detritus. Annual Review of Ecology and Systematics 8, 51-58.

Sollins, P.C., Glassman, P.A., Eldor, C., Swanston, K., Lajtha, J.W., HeilElliot, E.T., 1999. Soil carbon and nitrogen pools and fractions. In: Robertson, G.P., Coleman, D.C., Bledsoe, C.S., Sollins, P. (Eds.), Standard Soil Methods for Long-term Ecological Research. Oxford University Press, Oxford, NY, pp. 89-105.

Strand, E.K., Vierling, L.A., Smith, A.M.S., Bunting, S.C., 2008. Net changes in aboveground woody carbon stock in western juniper woodlands, 1946-1998. Journal of Geophysical Research 113, G01013. doi:10.1029/ 2007JG000544.

Ugolini, F.C., Corti, G., Agnelli, A., Piccardi, F., 1996. Minerological, physical, and chemical properties of rock fragments in soil. Soil Science 161 (8), 521-542.

Westerling, A.L., Hidalgo, H.G., Cayan, D.R., Swetnam, T.W., 2006. Warming and earlier spring increase western U.S. forest wildfire activity. Science 313, 940-943. 